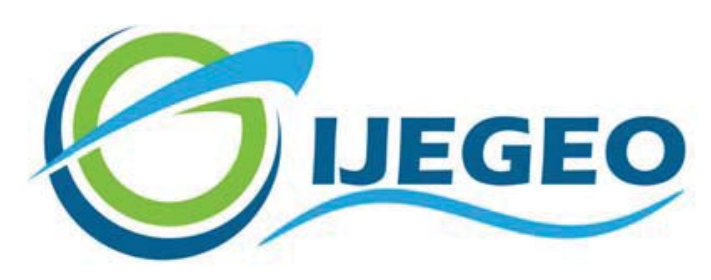

International Journal of Environment and Geoinformatics (IJEGEO) is an international, multidisciplinary, peer reviewed, open access journal.

\title{
Using Lean Six Sigma for Sustainability in Inbound Logistics: An Application in the Automotive Industry
}

\section{Mehmet Sıtkı SAYGILI, Erhan ÇIĞAL}

\author{
Chief in Editor \\ Prof. Dr. Cem Gazioğlu \\ Co-Editors Prof. Dr. Dursun Zafer Şeker, Prof. Dr. Şinasi Kaya, \\ Prof. Dr. Ayşegül Tanık and Assist. Prof. Dr. Volkan Demir
}

Editorial Committee (June 2022)

Assoc. Prof. Dr. Abdullah Aksu (TR), Assoc. Prof. Dr. Uğur Algancı (TR), Assoc. Prof. Dr. Aslı Aslan (US), Prof. Dr. Levent Bat (TR), Prof. Dr. Paul Bates (UK), İrşad Bayırhan (TR), Prof. Dr. Bülent

Bayram (TR), Prof. Dr. Luis M. Botana (ES), Prof. Dr. Nuray Çağlar (TR), Prof. Dr. Sukanta Dash (IN), Dr. Soofia T. Elias (UK), Prof. Dr. A. Evren Erginal (TR), Assoc. Prof. Dr. Cüneyt Erenoğlu (TR), Dr. Dieter Fritsch (DE), Prof. Dr. Ç; Prof. Dr. Manik Kalubarme (IN), Dr. Hakan Kaya (TR), Assist. Prof. Dr. Serkan Kükrer (TR), Assoc. Prof. Dr. Maged Marghany (MY); Prof. Dr. Micheal Meadows (ZA), Prof. Dr. Nebiye Musaoğlu (TR), Prof. Dr. Masafumi Nakagawa (JP), Prof. Dr. Hasan Özdemir (TR), Prof. Dr. Chyssy Potsiou (GR), Prof. Dr. Erol Sarı (TR), Prof. Dr. Maria Paradiso (IT), Prof. Dr. Petros Patias (GR), Prof. Dr. Elif Sertel (TR), Prof. Dr. Nüket Sivri (TR), Prof. Dr. Füsun

Balık Şanlı (TR), Dr. Duygu Ülker (TR), Prof. Dr. Seyfettin Tsaş (TR), Assoc. Prof. Dr. Ömer Suat Taşkın (TR), Assist. Prof. Dr. Tuba Ünsal (TR), Assist. Prof. Dr. Sibel Zeki (TR) 


\title{
Using Lean Six Sigma for Sustainability in Inbound Logistics: An Application in The Automotive Industry
}

\author{
Mehmet Sıtkı Saygılı iD , Erhan Çığal \\ University of Bahçeşehir, Vocational Schoool, 34353 Beşiktaş İstanbul Turkey \\ * Corresponding author: M.S. Saygilı \\ Received 27.07.2021 \\ Accepted 01.12.2021 \\ How to cite: Saygılı and Çı̆̆al (2022). Using Lean Six Sigma for Sustainability in Inbound Logistics: An Application in The Automotive \\ Industry, International Journal of Environment and Geoinformatics (IJEGEO), 9(2):108-119, doi.org/10.30897/ijegeo.975066
}

\begin{abstract}
Lean Six Sigma (LSS) is a method that aims to reduce waste and costs by decreasing defects in business processes, to increase efficiency and quality, to produce value-added goods/services, and to maintain this process. In this study, the LSS application is discussed as an implementation conducted by a company that is a supplier in the automotive industry, together with its customer in the main industry in order to improve the sustainable production process and quality. The results are evaluated in terms of effects on the customer regarding inbound logistics. Define, Measure, Analyze, Improve, Control (DMAIC) technique was used with 500-piece sample. Before the improvement, 41.7 defects occurred; whereas 8.7 after the improvement. As a result, shipping times of the customers operating in the main industry have been streamlined, stock costs have decreased, and sustainability has been achieved by reducing the waste of resources and energy for the environment.
\end{abstract}

Keywords: Inbound Logistics, Lean Six Sigma, Sustainability

\section{Introduction}

Inbound logistics is all physical and information flow activities from the ordering of materials, goods and services used in production to their entry into the factory (Takita and Leite, 2016). Proper management of inbound logistics ensures the supply of everything needed for sustainable production (Jejani et al., 2019). Companies that need to be ahead of their competitors in order to gain competitive advantage in the market (Verma and Seth, 2019) work with suppliers to improve the quality of the supplied material and improve the production process as part of the inbound logistics process (Dombrowski and Karl, 2016). The most important reason for this cooperation is that competition is now between supply chains rather than between businesses (Bhattacharya et al., 1995; Kehoe and Boughton, 2001) and therefore there is a need to increase the competitiveness of supply chain components.

One of the methods used to improve material quality and production processes is the Lean Six Sigma (LSS) method, which is a combination of Six Sigma methodology and lean philosophies. Six Sigma methodology is a roadmap for problem solving in the business process, consisting of Define, Measure, Analyze, Improve, and Control (DMAIC) stages (Krishnan and Prasath, 2013; Smętkowska and Mrugalska, 2018; Girmanová et al., 2017). It has a flexible structure that can be applied to all production and service processes (Fraser and Fraser 2011). It is also a common cross-organizational metric that takes into account customer demands, allowing for quality improvement (Tennant 2002). Lean philosophy promotes reduction of waste and non-value-added production, business standardization and sustainability of workflow (ASQ, 2021). Six Sigma focuses on eliminating defects and process variability, while lean thinking focuses on waste and speed in all processes (George, 2002). By applying these two structures simultaneously, process speed, product/service quality and customer satisfaction can be increased while costs can be reduced (Christopher and Rutherford, 2004). In addition, the goals of Lean Six Sigma, i.e. reducing defects, accelerating production, better management of inventory, reducing the number and costs of transportation, are also in line with the environmental sustainability goals of the companies. Thus, cooperation is ensured in the environmentally friendly production of ready-made parts and final products to be produced with a green supply chain perspective (Huo et al., 2019). The wastes aimed to be prevented by the lean philosophy and their environmental effects are shown in Table 1. Elimination of defects and reduction of waste provide environmental benefits (USEPA, 2020).

In the literature, there are various studies on the use of Lean Six Sigma method in logistics business processes. As a result of the study conducted by Mijajlevski (2013) on the distribution planning of a manufacturer of domestic water heating equipment, route planning errors and average route time were reduced. In the study conducted by Zhang et al. (2016) on companies implementing Lean Six Sigma to improve logistics operations, varying degrees of cost savings and productivity improvement were achieved in all 
implementing companies. In the study conducted by Gutierrez-Gutierrez et al. (2016), a Lean Six Sigma method was used to continuously improve the payment and shipping process of a consumer electronics company, and it was seen that this increased the quality of logistics service. According to a study by Linares et al. (2019), the loading process in a paper mill was evaluated with the Lean Six Sigma method, and there was an increase in performance and a decrease in cycle time in the business process. While all abovementioned studies take into account customer demands for improvement, it is seen that companies apply the Lean
Six Sigma method to their own business processes. Unlike the ones in the literature, in this study, Lean Six Sigma method was applied with the joint participation of the customer and supplier to increase the power of the supply chain components. In this context, the aim of the study is to use the Lean Six Sigma method to improve the production process and quality of the supplier that provides equipment to a manufacturer in the automotive main industry and the results are evaluated in terms of cost and environmental sustainability within the scope of inbound logistics for the manufacturing company in the main industry.

Table 1. Waste aimed to be prevented with a lean philosophy and its environmental effects

\begin{tabular}{|c|c|}
\hline Lean Waste Type & Environmental Impacts \\
\hline $\begin{array}{l}\text { Overproduction } \\
\text { Manufacturing items for which } \\
\text { there are no orders }\end{array}$ & $\begin{array}{l}\text { - More raw materials consumed in making the unneeded products } \\
\text { - Extra products may spoil or become obsolete requiring disposal }\end{array}$ \\
\hline $\begin{array}{l}\text { Inventory } \\
\text { Excess raw material, work in } \\
\text { process, or finished goods }\end{array}$ & $\begin{array}{l}\text { - Raw materials and energy consumed in making defective products } \\
\text { - Defective components require recycling or disposal } \\
\text { - More space required for rework and repair, increasing energy use for } \\
\text { heating, cooling, and lighting }\end{array}$ \\
\hline $\begin{array}{l}\text { Transportation } \\
\text { Excess transport of work in } \\
\text { process } \\
\text { Motion } \\
\text { Human movements that are } \\
\text { unnecessary or straining }\end{array}$ & $\begin{array}{l}\text { - More energy use for transport } \\
\text { - Emissions from transport } \\
\text { - More space required for work in process movement, increasing lighting, } \\
\text { heating, and cooling demand and energy use } \\
\text { - More packaging required to protect components during movement } \\
\text { - Damage and spills during transport } \\
\text { - Transportation of hazardous materials requires special packaging to } \\
\text { prevent risk during accidents }\end{array}$ \\
\hline $\begin{array}{l}\text { Over processing } \\
\text { Process steps that are not } \\
\text { required to produce the product }\end{array}$ & $\begin{array}{l}\text { - More parts and raw materials consumed per unit of production } \\
\text { - Unnecessary processing increases wastes, energy use, and emissions }\end{array}$ \\
\hline $\begin{array}{l}\text { Waiting } \\
\text { Delays associated with stock } \\
\text { outs, equipment downtime, } \\
\text { capacity bottlenecks }\end{array}$ & $\begin{array}{l}\text { - Potential material spoilage or component damage causing waste } \\
\text { - Wasted energy from heating, cooling, and lighting during production } \\
\text { downtime }\end{array}$ \\
\hline
\end{tabular}

\section{Materials and Method}

The aim of the study is improving the production process and quality of the parts assembled by arc welding and supplied by a manufacturer operating in the automotive main industry. As the parts that are shipped with faulty production cannot be used in the main industry, they cause prolongation of the shipment and supply process and adversely affect inventory planning within the scope of inbound logistics. In fact, if these parts are mounted on the vehicle by accident, they may cause the entire vehicle to be repaired or scrapped in the main industry due to their location and functions. All these factors increase the supply costs of the main industry producer; also, the extra materials and energy consumed negatively affect the environment. For this reason, the Lean Six Sigma method was applied by the employees of the two companies together to ensure improvement and sustainability in the production process of the supplier in the sub-industry and to evaluate the effects of this situation on the inbound logistics processes of the customer in the main industry.

In the Define phase, which is the first step of the DMAIC process, the whole process is evaluated and a roadmap is drawn up on where and how to find the problem (The Council for Six Sigma Certification, 2018:169). In this process, with the support of the senior management of both companies, the employees worked together and defined the project process; thereafter a project statement was created, and improvement teams were established.

The purpose of Measure phase, which is the next process, is to collect as much information as possible using qualitative and/or quantitative methods in order to understand the status of the current process and how it works (Desai, 2010). At this stage, various methods were utilized to obtain information to be used in the analysis of manufacturing defects. In this framework, data about processes were collected using control charts, pareto charts, "Suppliers, Inputs, Process, Outputs, Customers" (SIPOC) diagrams.

After the Measure phase, sufficient information is obtained about the situation and conditions of the problem. Then, in the Analyze phase, an answer is sought for why the problem occurred. The main purpose here is to identify potential root causes and then confirm them with data since the Improvement process cannot be started without finding the root causes of the problem (Desai, 2010). Function equation of the problem in all 
Lean Six Sigma projects formulated as $y=f(x)$. In the formula, $y$ is the output resulting from the request or requirement. $x$ represents the inputs, factors or parts that make up the outputs and there can be more than one $\mathrm{x}$. The responsibility of the Lean Six Sigma team here is to analyze each $x$ in the $y=f(x)$ function, to identify the root causes of the problem and to investigate its effect on the y output. After adequate analysis, various theories are developed to determine the basis of the problem. These theories are tested so that root causes can be verified (Kumar, 2006). In this framework, in the analysis phase of the study, fishbone diagram, causeeffect matrix and action plans were created in the light of the data obtained. The results of the analyzes were observed during the production process and their effects on welding faults were investigated.

In the Improve phase of Six Sigma, it is aimed to improve the root causes affecting the performance of the product and to reach the desired level (Park, 2003). In this phase, teams often turn to solutions that seem the fastest and simplest; however, solving problems can be more complex and difficult than they seem. Therefore, it is necessary to be sure that the decision taken in the improvement phase will eliminate the problem (Thomsett, 2005). The final phase is Control and it is evaluated whether the targeted quality level has been achieved by measuring the effects of the improvements and corrections.

\section{Results}

In the study, first of all, the problem to which Lean Six Sigma method will be applied is defined. Accordingly, the focus is on manufacturing defects in a bracket and custom-made pipe sub-parts assembled with gas metal arc welding. In order to guarantee the quality of the parts, production is required according to the standards determined by the main industrial vehicle manufacturer. These are dimensional, visual and source quality standards. By reducing the defect rates by meeting the determined standards, it is expected that the inventory will be better managed, the costs will be reduced and environmentally friendly production will be made by reducing the amount of waste in the supply chain.

The defect types related to the selected part group are shown in Figure 1 compared to other defect types, it is seen that the defects related to gas metal arc welding problems come first in the part. For this reason, it has been decided to make a Lean Six Sigma project for welding defects by the main industry producer company and supplier industry, which are the project stakeholders. By creating a project statement, business processes were defined, improvement teams were established with the participation of experts from both companies, and a project plan was created.

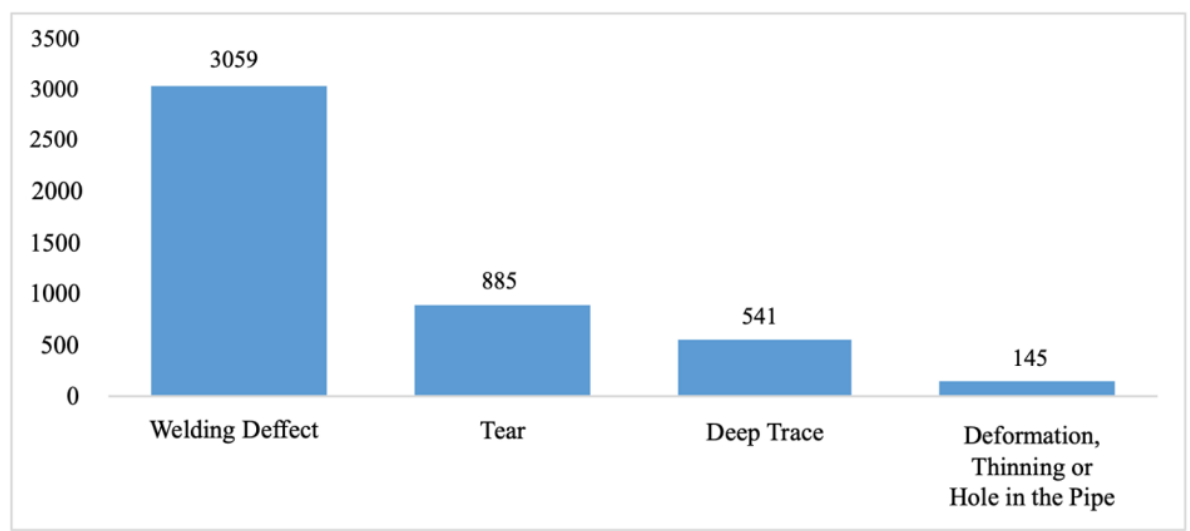

Fig. 1. Part defect types and numbers

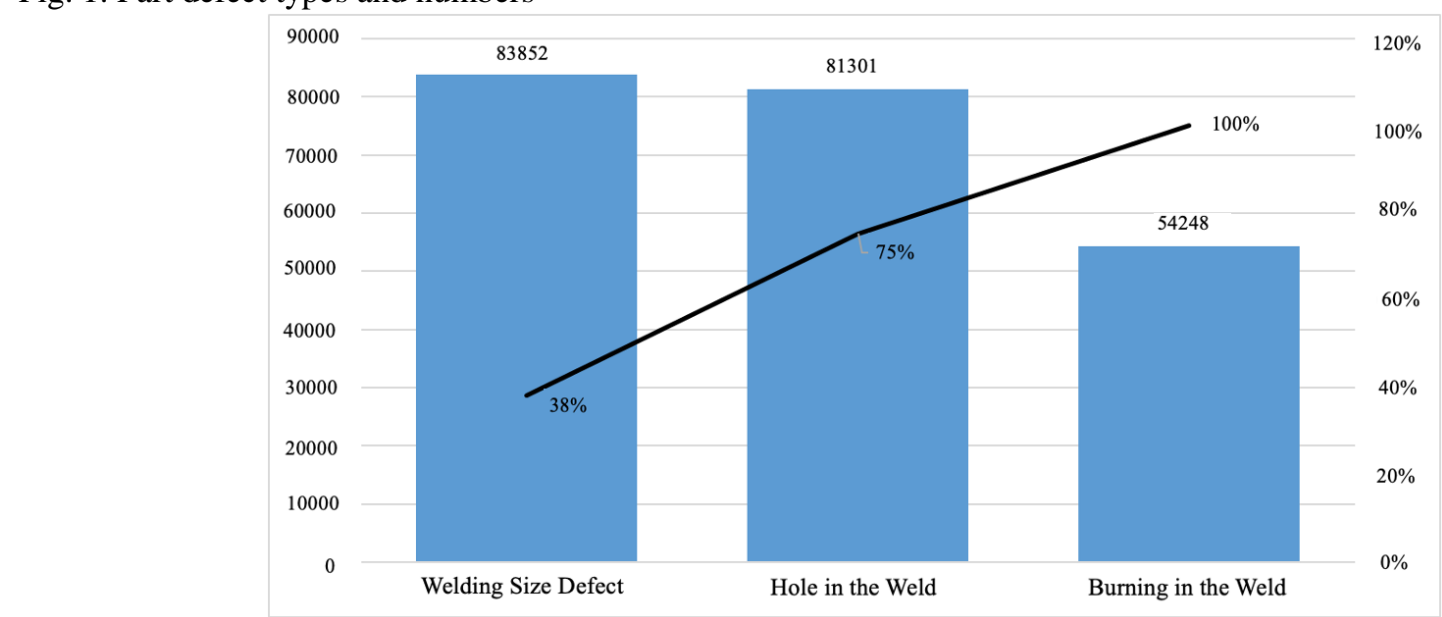

Fig. 2. Welding defect types DPMO pareto chart

During the measurement phase, the data of the past six months on welding defects were examined. According to these data, three defect types were encountered. These defects were detected as incorrect weld length, hole in 
the weld and burning in the weld, as shown in Figure 2. Incorrect weld length is the defect that occurs as a result of the weld length of the part being outside the tolerance specified in the supply contract of the main industry manufacturer, namely $28 \mathrm{~mm}-33 \mathrm{~mm}$. Hole defects in welding are small pin holes formed on the weld; whereas burning in welding is the defect that occurs as a result of perforation of the part during welding.
In order to detect the defects in the current situation, the defect rate and the number of defects were determined by making measurements on 500 pieces of production made in twenty shifts. While p control charts were used to determine the defect rate, np control charts were used to determine the number of defects (Y1ldirim et al., 2018). According to the $P$ control chart in Figure 3, the average defect rate was determined as 0.0833 . According to the NP control chart in Figure 4, the number of defects in 500 measurements was determined as 41.7 .

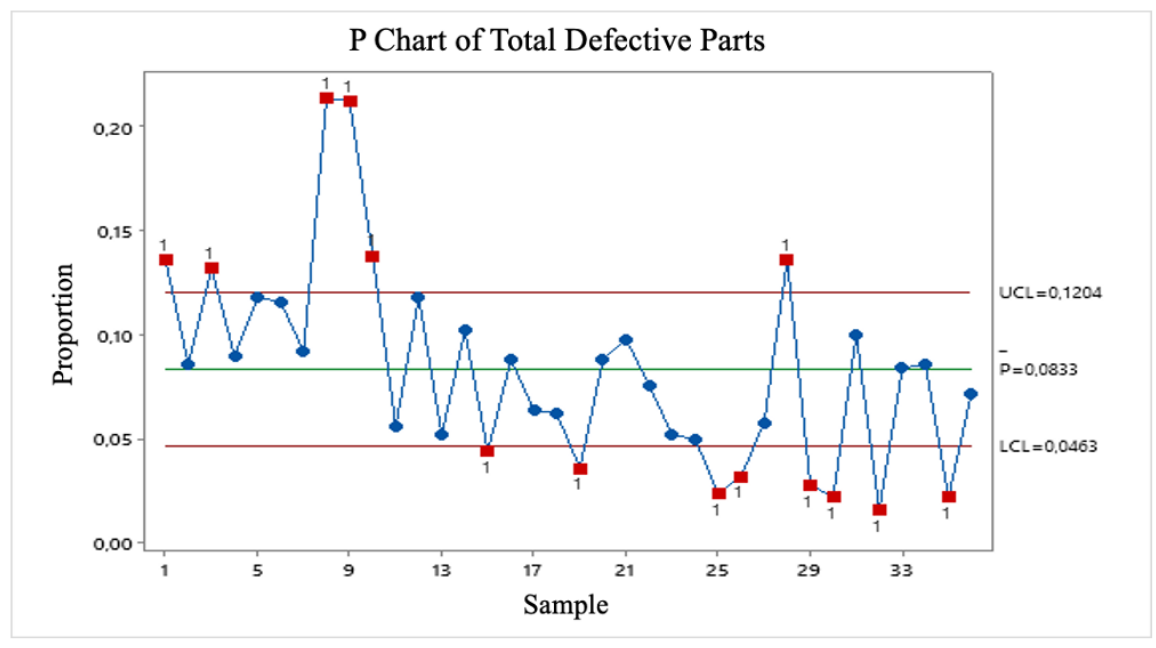

Fig.3. Part P control chart

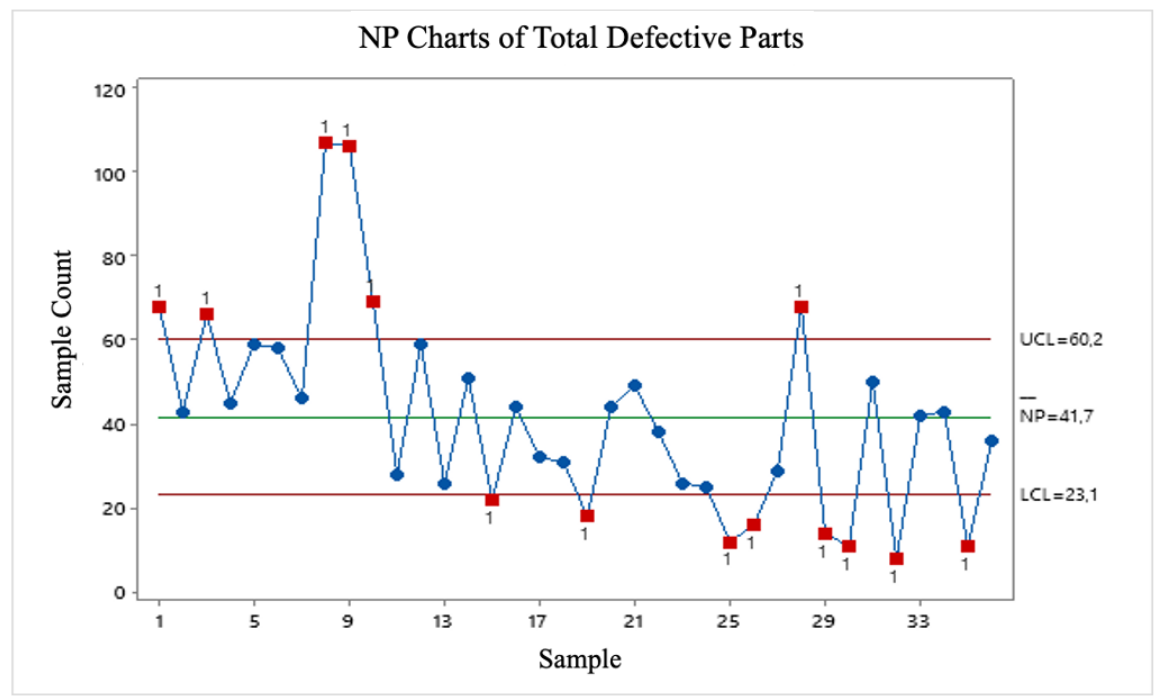

Fig. 4. Part NP control chart

Part production process consists of press operation, supply of sub-parts, welding operation and final control/shipment operation, respectively. The SIPOC diagram in Table 2 shows in which operation the problem started and the inputs in this operation. The inputs in the operation where the defect occurred are reference to understand the root cause of the problem. The selected part group consists of two sub-parts, a bracket and a pipe. The bracket part is manufactured by the company, while the pipe lower part is supplied from another supplier. The basic production process of the bracket part starts with the press operation. In the supply of lower parts, the required quantities of pipe and bracket parts are calculated and transported to the stock areas for welding production and stocked. The parts supplied in the welding operation are joined by gas metal arc welding. In the final control and shipment process, the parts are shipped in shipping boxes after undergoing visual and dimensional control Then, as seen in the Quality Characteristics (CTQ) tree in Figure 5, it was determined that, " 0 " defect for the number of defects, " 0 " defect for the scrap count, " 0 " defect for the number of reworks, " 0 " defect for the final control is required and defect-free measures should be applied to make the production process defect-free. 


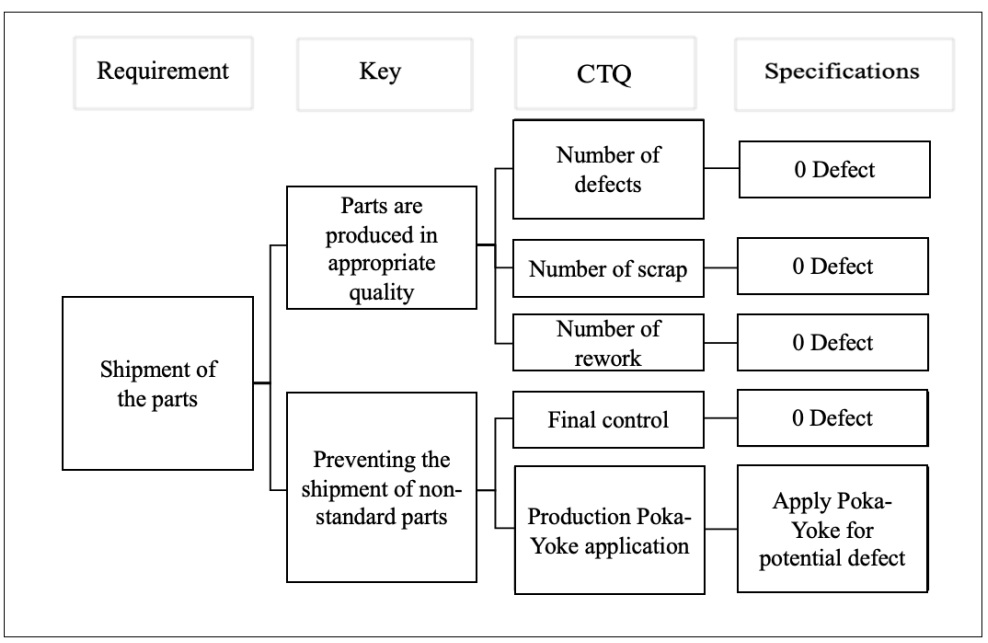

Fig. 5. CTQ Tree

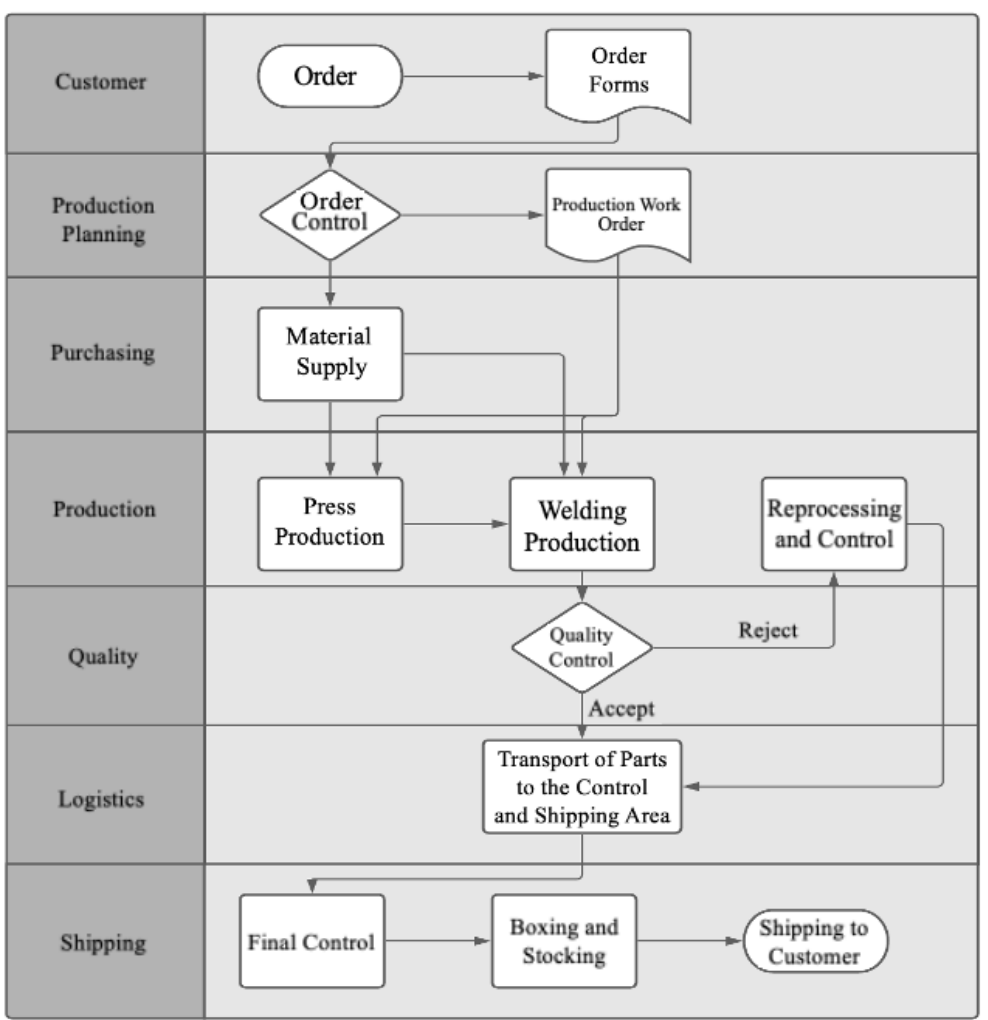

Fig. 6. Process information

Table 2. SIPOC Diagram

\begin{tabular}{|c|c|c|c|c|}
\hline Supplier & Inputs & Process & Outputs & Customers \\
\hline $\begin{array}{l}\text { 1.Sheet Supplier } \\
\text { 2.Press Company } \\
\text { 3.Driver Company } \\
\text { 4.Molding Room }\end{array}$ & $\begin{array}{l}\text { 1.Sheet } \\
\text { 2.Press } \\
\text { 3.Driver } \\
\text { 4.Mold }\end{array}$ & Press & Bracket & $\begin{array}{l}\text { Logistics } \\
\text { Department }\end{array}$ \\
\hline $\begin{array}{l}\text { 1.Raw Material } \\
\text { Supplier } \\
\text { 2.Press Production }\end{array}$ & $\begin{array}{l}\text { 1.Pipe } \\
\text { 2.Bracket }\end{array}$ & Bottom Part Supply & $\begin{array}{l}\text { Transported and } \\
\text { Stocked Part }\end{array}$ & Weld Production \\
\hline $\begin{array}{l}\text { 1.Wire Supplier } \\
\text { 2.Robot Producer } \\
\text { 3.Jig Producer } \\
\text { 4.Gas Supplier } \\
\text { 5.Support Supply } \\
\text { 6.PLC Producer } \\
\text { 7.Logistics }\end{array}$ & $\begin{array}{l}\text { 1.Welding Wire } \\
\text { 2.Robot } \\
\text { 3.Jig } \\
\text { 4.Gas } \\
\text { 5.Nozzle } \\
\text { 6.PLC Program } \\
\text { 7.Bottom Part }\end{array}$ & Welding & Welded Part & Shipping \\
\hline $\begin{array}{l}\text { 1.Customer } \\
\text { 2.Control Fixture } \\
\text { Producer } \\
\text { 3.Forklift } \\
\text { 4.Customer } \\
\text { 5.Welding } \\
\text { Production }\end{array}$ & $\begin{array}{l}\text { 1.Box } \\
\text { 2.Control Fixture } \\
\text { 3.Forklift } \\
\text { 4.Manifest / } \\
\text { Kanban } \\
\text { 5.Welded Part }\end{array}$ & $\begin{array}{l}\text { Final Control / } \\
\text { Shipping }\end{array}$ & $\begin{array}{l}\text { Boxed Item/ Ready } \\
\text { to Shipping }\end{array}$ & Final Customer \\
\hline
\end{tabular}


Then, process mapping was done. The process information that the part follows from the moment it is ordered to the moment it is shipped is shown in Figure 6. Process mapping is an effective tool for visualizing operations that add value to the main industry producer, which is the customer of the supplier, and that affect the output. After the quality control operation, it is planned to accommodate the detected defects through reprocessing and to transport them with the defect-free parts to the final control area with the help of forklifts. Quality operators decide whether a manufactured product is defected or not. The accuracy of the decisions made is of great importance for the results to guide the Lean Six Sigma team correctly. Measurement systems analysis was used to analyze the accuracy of the quality operators' defect detections. For this purpose, Gage R\&R analysis was performed. This analysis is widely used to evaluate measurement systems (Satic1 et al., 2020). Analysis of weld length is shown in Table 3. Accordingly, firstly, 15 sample pieces were selected for two quality operators. The measurement of the sample pieces was first made by an expert and the nominal value was found. It was then performed by Operator 1 and Operator 2 in two repetitions.

Table 3. Weld length measurement

\begin{tabular}{|c|c|c|c|c|c|}
\hline \multirow{2}{*}{ Measuring Order } & \multirow{2}{*}{ Nominal $(\mathrm{mm})$} & \multicolumn{2}{|c|}{ Operator 1 } & \multicolumn{2}{c|}{ Operator 2 } \\
\cline { 3 - 6 } & & $\begin{array}{c}\text { Repetition } \\
1\end{array}$ & $\begin{array}{c}\text { Repetition } \\
2\end{array}$ & $\begin{array}{c}\text { Repetition } \\
1\end{array}$ & $\begin{array}{c}\text { Repetition } \\
2\end{array}$ \\
\hline $\mathbf{1}$ & 29,30 & 30,11 & 30,14 & 30,13 & 30,09 \\
\hline $\mathbf{2}$ & 30,40 & 29,98 & 30,10 & 30,24 & 30,25 \\
\hline $\mathbf{3}$ & 29,00 & 29,31 & 29,41 & 29,18 & 29,14 \\
\hline $\mathbf{4}$ & 29,60 & 29,42 & 29,43 & 29,20 & 29,26 \\
\hline $\mathbf{5}$ & 30,00 & 29,65 & 29,53 & 29,67 & 29,69 \\
\hline $\mathbf{6}$ & 29,80 & 29,62 & 29,74 & 29,68 & 29,59 \\
\hline $\mathbf{7}$ & 29,45 & 29,67 & 29,65 & 29,70 & 29,54 \\
\hline $\mathbf{8}$ & 29,20 & 29,87 & 30,01 & 30,12 & 29,88 \\
\hline $\mathbf{9}$ & 29,60 & 29,47 & 29,48 & 29,58 & 29,50 \\
\hline $\mathbf{1 0}$ & 29,70 & 29,70 & 29,79 & 29,61 & 29,69 \\
\hline $\mathbf{1 1}$ & 29,87 & 29,80 & 29,81 & 29,86 & 29,79 \\
\hline $\mathbf{1 2}$ & 30,04 & 30,15 & 30,01 & 30,10 & 29,96 \\
\hline $\mathbf{1 3}$ & 30,10 & 30,05 & 30,05 & 30,05 & 30,16 \\
\hline $\mathbf{1 4}$ & 29,65 & 29,72 & 29,68 & 29,69 & 29,62 \\
\hline $\mathbf{1 5}$ & 29,98 & 29,88 & 29,95 & 30,02 & 30,04 \\
\hline
\end{tabular}

Table 4. Weld length gage $\mathrm{R} \& \mathrm{R}$ results

\begin{tabular}{|ccc|}
\hline Source & VarComp & $\begin{array}{c}\text { \%Contribution } \\
\text { (of VarComp) }\end{array}$ \\
Total Gage R\&R & 0,0082565 & 9,93 \\
Repeatability & 0,0046817 & 5,63 \\
Reproducibility & 0,0035749 & 4,30 \\
Operator & 0,0000000 & 0,00 \\
Operator*Measurement & 0,0035749 & 4,30 \\
Rank & & \\
Part-To-Part & 0,0748492 & 90,07 \\
Total Variation & 0,0831057 & 100,00 \\
\hline
\end{tabular}

The measurement results were analyzed by Minitab19 and the results in Table 4 were obtained. According to the results, the Total Gage $R \& R$ value was found to be $9.93 \%$. This value is expected to be $<10 \%$ for the adequacy of measurement systems. Although the result is close to the limit, it was accepted that the measurement system was sufficient since it remained within the limit.

As seen in Table 5, the measurement of sample parts related to the appearance of holes in the weld was first made by an expert and the nominal value was found. It was then measured by Operator 1 and Operator 2 in two repetitions. The measurement results were analyzed by Minitab19 and the results shown in Figure 7 were obtained. Accordingly, Operator 1 and Operator 2 measurements are $100 \%$ consistent within themselves. In addition, it is seen that the measurements of Operator 1 and Operator 2 are $100 \%$ consistent with the measurements made by the expert. As seen in Table 6, the measurement of sample parts related to the occurrence of burning in the weld was conducted by an expert and the nominal value was found. It was then measured by Operator 1 and Operator 2 with two repetitions. The measurement results were analyzed by Minitab19 and the results in Figure 8 were obtained. Accordingly, repeated measurements by Operator 1 and Operator 2 are $100 \%$ consistent within themselves. In addition, it is seen that the measurements of Operator 1 and Operator 2 are $100 \%$ consistent with the measurements conducted by the expert. 
Table 5. Hole gage R\&R measurement at weld

\begin{tabular}{|c|c|c|c|c|c|}
\hline \multirow{2}{*}{$\begin{array}{c}\text { Measuring } \\
\text { Order }\end{array}$} & \multirow{2}{*}{ Nominal(mm) } & \multicolumn{2}{|c|}{ Operator 1} & \multicolumn{2}{c|}{ Operator 2} \\
\hline & & $\begin{array}{c}\text { Repetition } \\
1\end{array}$ & $\begin{array}{c}\text { Repetition } \\
2\end{array}$ & $\begin{array}{c}\text { Repetition } \\
1\end{array}$ & $\begin{array}{c}\text { Repetition } \\
2\end{array}$ \\
\hline $\mathbf{1}$ & ABSENT & ABSENT & ABSENT & ABSENT & ABSENT \\
\hline $\mathbf{2}$ & ABSENT & ABSENT & ABSENT & ABSENT & ABSENT \\
\hline $\mathbf{3}$ & ABSENT & ABSENT & ABSENT & ABSENT & ABSENT \\
\hline $\mathbf{4}$ & ABSENT & ABSENT & ABSENT & ABSENT & ABSENT \\
\hline $\mathbf{5}$ & ABSENT & ABSENT & ABSENT & ABSENT & ABSENT \\
\hline $\mathbf{6}$ & ABSENT & ABSENT & ABSENT & ABSENT & ABSENT \\
\hline $\mathbf{7}$ & ABSENT & ABSENT & ABSENT & ABSENT & ABSENT \\
\hline $\mathbf{8}$ & ABSENT & ABSENT & ABSENT & ABSENT & ABSENT \\
\hline $\mathbf{9}$ & ABSENT & ABSENT & ABSENT & ABSENT & ABSENT \\
\hline $\mathbf{1 0}$ & ABSENT & ABSENT & ABSENT & ABSENT & ABSENT \\
\hline $\mathbf{1 1}$ & PRESENT & PRESENT & PRESENT & PRESENT & PRESENT \\
\hline $\mathbf{1 2}$ & ABSENT & ABSENT & ABSENT & ABSENT & ABSENT \\
\hline $\mathbf{1 3}$ & ABSENT & ABSENT & ABSENT & ABSENT & ABSENT \\
\hline $\mathbf{1 4}$ & ABSENT & ABSENT & ABSENT & ABSENT & ABSENT \\
\hline $\mathbf{1 5}$ & PRESENT & PRESENT & PRESENT & PRESENT & PRESENT \\
\hline
\end{tabular}

Table 6. Combustion gage R\&R measurement at source

\begin{tabular}{|c|c|c|c|c|c|}
\hline \multirow{2}{*}{$\begin{array}{c}\text { Measuring } \\
\text { Order }\end{array}$} & \multirow{2}{*}{ Nominal(mm) } & \multicolumn{2}{|c|}{ Operator 1} & \multicolumn{2}{c|}{ Operator 2 } \\
\cline { 3 - 6 } & & $\begin{array}{c}\text { Repetition } \\
1\end{array}$ & $\begin{array}{c}\text { Repetition } \\
2\end{array}$ & $\begin{array}{c}\text { Repetition } \\
1\end{array}$ & $\begin{array}{c}\text { Repetition } \\
2\end{array}$ \\
\hline $\mathbf{1}$ & ABSENT & ABSENT & ABSENT & ABSENT & ABSENT \\
\hline $\mathbf{2}$ & ABSENT & ABSENT & ABSENT & ABSENT & ABSENT \\
\hline $\mathbf{3}$ & ABSENT & ABSENT & ABSENT & ABSENT & ABSENT \\
\hline $\mathbf{4}$ & ABSENT & ABSENT & ABSENT & ABSENT & ABSENT \\
\hline $\mathbf{5}$ & PRESENT & PRESENT & PRESENT & PRESENT & PRESENT \\
\hline $\mathbf{6}$ & ABSENT & ABSENT & ABSENT & ABSENT & ABSENT \\
\hline $\mathbf{7}$ & ABSENT & ABSENT & ABSENT & ABSENT & ABSENT \\
\hline $\mathbf{8}$ & PRESENT & PRESENT & PRESENT & PRESENT & PRESENT \\
\hline $\mathbf{9}$ & ABSENT & ABSENT & ABSENT & ABSENT & ABSENT \\
\hline $\mathbf{1 0}$ & PRESENT & PRESENT & PRESENT & PRESENT & PRESENT \\
\hline $\mathbf{1 1}$ & ABSENT & ABSENT & ABSENT & ABSENT & ABSENT \\
\hline $\mathbf{1 2}$ & ABSENT & ABSENT & ABSENT & ABSENT & ABSENT \\
\hline $\mathbf{1 3}$ & ABSENT & ABSENT & ABSENT & ABSENT & ABSENT \\
\hline $\mathbf{1 4}$ & ABSENT & ABSENT & ABSENT & ABSENT & ABSENT \\
\hline $\mathbf{1 5}$ & ABSENT & ABSENT & ABSENT & ABSENT & ABSENT \\
\hline
\end{tabular}

Assessment Agreement
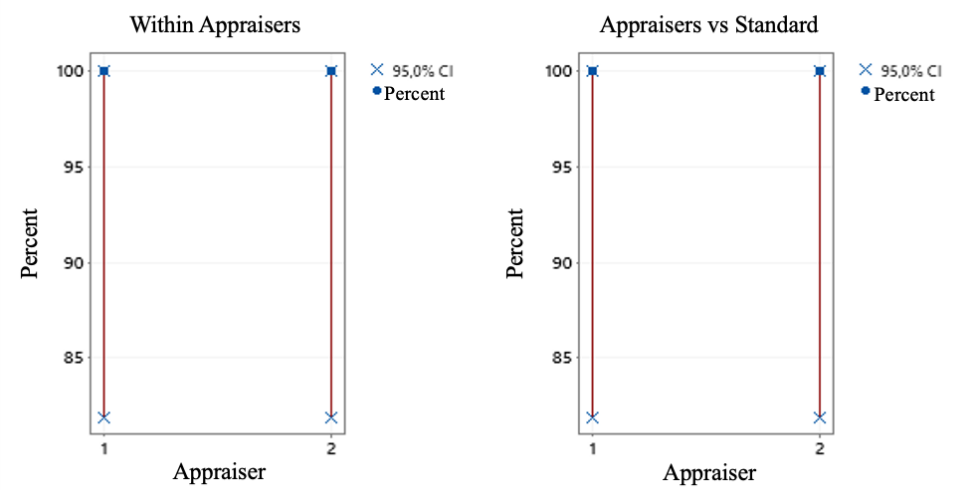

Fig. 7. Hole gage R\&R result in weld 
Assessment Agreement
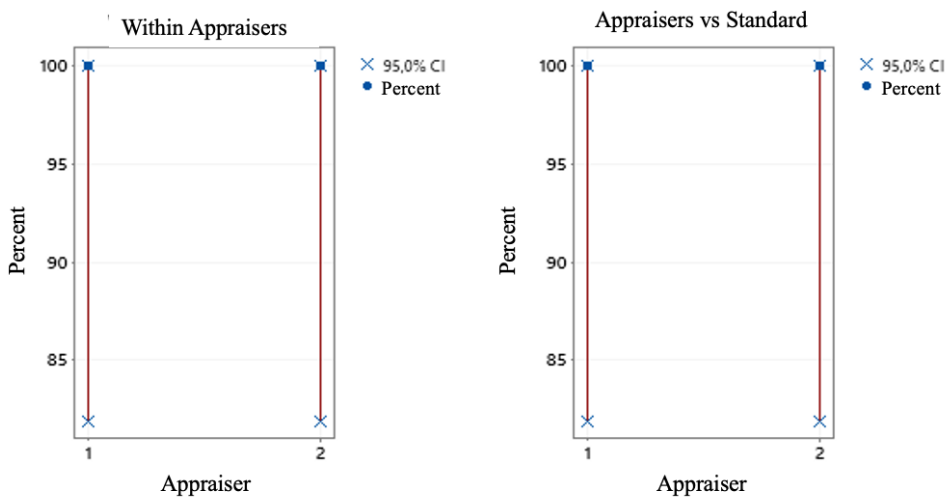

Fig. 8. Weld burn gage R\&R measure result

As a result of the measurement systems competence analysis, it was observed that the operator evaluations regarding three different defects were sufficient, and the measurement reliability of the operators was confirmed. In the analysis process, the causes of the problems were determined by making a fishbone diagram about the welding defects. These causes were divided according to defect types in the cause-effect matrix in Table 7 and scored according to their probability of occurrence. The root cause with the highest score is prioritized. Accordingly, some improvements were made on-site, while an improvement plan was created for others.

For the improvements and corrections that could not be made on-site, a six-week improvement plan was made, as seen in Table 8. During the root cause checks, it was decided to design an experiment on part surface cleaning, welding current and gas flow parameters.

Table 7. Welding defects cause and effect table

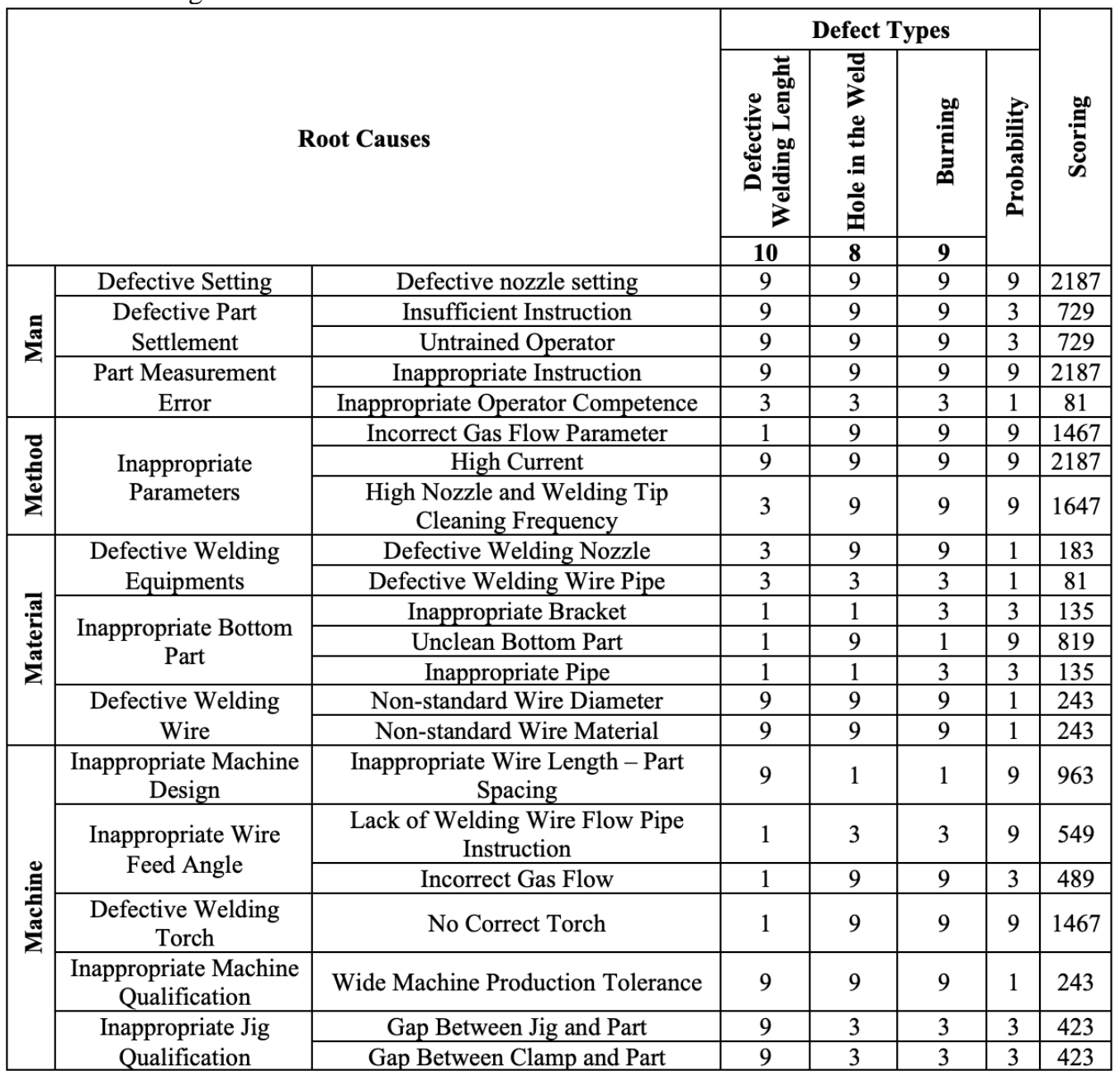


Table 8: Improvement plan

\begin{tabular}{|c|c|c|c|c|c|c|c|c|c|c|}
\hline \multirow{2}{*}{$\#$} & \multirow{2}{*}{ Root Causes } & \multirow{2}{*}{ Improvement Points } & \multicolumn{7}{|c|}{ Plan(Week) } & \multirow{2}{*}{ Result } \\
\hline & & & $\mathbf{N}$ & $\mathbf{N}+1$ & $\mathbf{N}+2$ & $\mathbf{N}+3$ & $\mathrm{~N}+4$ & $\mathrm{~N}+5$ & $\mathrm{~N}+6$ & \\
\hline \multirow{2}{*}{1} & \multirow{2}{*}{ Defective Nozzle Setting } & 1-Preparation of Nozzle Adjustment Instruction & & & & & & & & Done \\
\hline & & 2-Increasing the Frequency of Nozzle Change & & & & & & & & Done \\
\hline \multirow{2}{*}{2} & \multirow{2}{*}{ Insufficient Part Settlement Instruction } & 1-Revision of Work Instructions & & & & & & & & Done \\
\hline & & 2-Training the Operators & & & & & & & & Done \\
\hline \multirow{2}{*}{3} & \multirow{2}{*}{ Insufficient Part Measuring Instruction } & 1-Revision of Work Instructions & & & & & & & & Done \\
\hline & & 2-Training the Operators & & & & & & & & Done \\
\hline 6 & $\begin{array}{l}\text { Nozzle and Welding Tip Cleaning } \\
\text { Frequency is High }\end{array}$ & 1-Increasing the Frequency of Nozzle Change & & & & & & & & Done \\
\hline 7 & Incorrect Welding Wire Pipe & $\begin{array}{l}\text { 1-Replacement of Welding Wire Conduction } \\
\text { Pipe }\end{array}$ & & & & & & & & Done \\
\hline 9 & $\begin{array}{l}\text { Inappropriate Wire Lenght - Part } \\
\text { Spacing }\end{array}$ & $\begin{array}{l}\text { 1-Checking the Distance Between the Tip of the } \\
\text { Welding Wire and the Part }\end{array}$ & & & & & & & & Done \\
\hline \multirow{2}{*}{10} & \multirow{2}{*}{$\begin{array}{l}\text { Insufficient Part Surface Cleaning, } \\
\text { Welding Current, Gas Flow Parameters }\end{array}$} & 1-Making Full Factorial Experiment Design & & & & & & & & Done \\
\hline & & $\begin{array}{l}\text { 2-Making Standardization According to New } \\
\text { Parameters }\end{array}$ & & & & & & & & Done \\
\hline
\end{tabular}

Table 9. Welding parameters experiment design

\begin{tabular}{|l|l|l|l|}
\hline & Welding Current (A) & \multicolumn{1}{|c|}{$\begin{array}{c}\text { Gas Flow } \\
(\text { L/Min) }\end{array}$} & \multicolumn{1}{c|}{ Part Cleanliness } \\
\hline $\mathbf{1}$ & 75 & 10 & Clean \\
\hline $\mathbf{2}$ & 85 & 12 & Unclean \\
\hline
\end{tabular}

Table 10. Experiment design measurement result table

\begin{tabular}{|c|c|c|c|c|c|c|c|c|}
\hline \multirow[t]{2}{*}{ Sorting } & \multirow{2}{*}{$\begin{array}{c}\text { Ampere } \\
(\mathrm{A})\end{array}$} & \multirow{2}{*}{$\begin{array}{l}\text { Gas Flow } \\
\text { (L/Min.) }\end{array}$} & \multirow{2}{*}{$\begin{array}{c}\text { Part } \\
\text { Situation }\end{array}$} & \multirow{2}{*}{$\begin{array}{c}\text { Total } \\
\text { Production }\end{array}$} & \multicolumn{3}{|c|}{ Number of Defects } & \multirow[t]{2}{*}{ DPMO } \\
\hline & & & & & Short Weld & Hole & Burning & \\
\hline 1 & 85 & 12 & Clean & 30 & 1 & 0 & 0 & 33333 \\
\hline 2 & 75 & 10 & Unclean & 30 & 1 & 0 & 0 & 33333 \\
\hline 3 & 85 & 10 & Clean & 90 & 1 & 0 & 0 & 11111 \\
\hline 4 & 85 & 10 & Clean & 190 & 1 & 0 & 0 & 5263 \\
\hline 5 & 75 & 12 & Clean & 190 & 4 & 0 & 0 & 21053 \\
\hline 6 & 85 & 10 & Unclean & 30 & 1 & 0 & 0 & 33333 \\
\hline 7 & 85 & 12 & Unclean & 60 & 1 & 0 & 0 & 16667 \\
\hline 8 & 75 & 10 & Clean & 60 & 1 & 0 & 0 & 16667 \\
\hline 9 & 85 & 12 & Unclean & 90 & 1 & 0 & 0 & 11111 \\
\hline 10 & 75 & 10 & Clean & 60 & 1 & 0 & 0 & 16667 \\
\hline 11 & 75 & 12 & Unclean & 190 & 3 & 0 & 0 & 15789 \\
\hline 12 & 75 & 12 & Unclean & 90 & 0 & 0 & 0 & 11111 \\
\hline 13 & 75 & 10 & Unclean & 30 & 1 & 0 & 0 & 33333 \\
\hline 14 & 85 & 10 & Unclean & 90 & 2 & 0 & 0 & 22222 \\
\hline 15 & 85 & 12 & Clean & 30 & 3 & 0 & 0 & 100000 \\
\hline 16 & 75 & 12 & Clean & 90 & 1 & 0 & 0 & 11111 \\
\hline
\end{tabular}

In the Improve Phase, improvement plans that were determined according to the findings obtained during the analyze phase were implemented. In the previous analysis, it was decided to design a three-factor and twolevel experiment, since it was concluded that the parameters related to welding current, gas flow and part surface would have a significant effect on welding defects. As seen in Table 9, the levels were determined such that the welding current was $75 \mathrm{~A}$ and $85 \mathrm{~A}$, the gas flow was $10 \mathrm{~L} / \mathrm{Min}$ and $12 \mathrm{~L} / \mathrm{Min}$, and parts were either cleaned or not cleaned. A total of sixteen trials, with eight different trials and two repetitions, were conducted according to the full factorial experimental design method. Defect types, number of defects and defects per million opportunities (DPMO) results are shown in Table 10.

The results were analyzed by Minitab19 at $95 \%$ confidence level. Accordingly, as seen in Figure 9, while the parameters on the left side of the value given by the dashed line did not make a significant contribution to the result, the parameter on the right side of the value contributed significantly to the result. The parameter affecting the result was determined as the combination of gas flow and part surface parameters, which are seen as BC. 


\section{Pareto Chart of the Standardized Effects \\ (response is DPMO; $\alpha=0,05$}

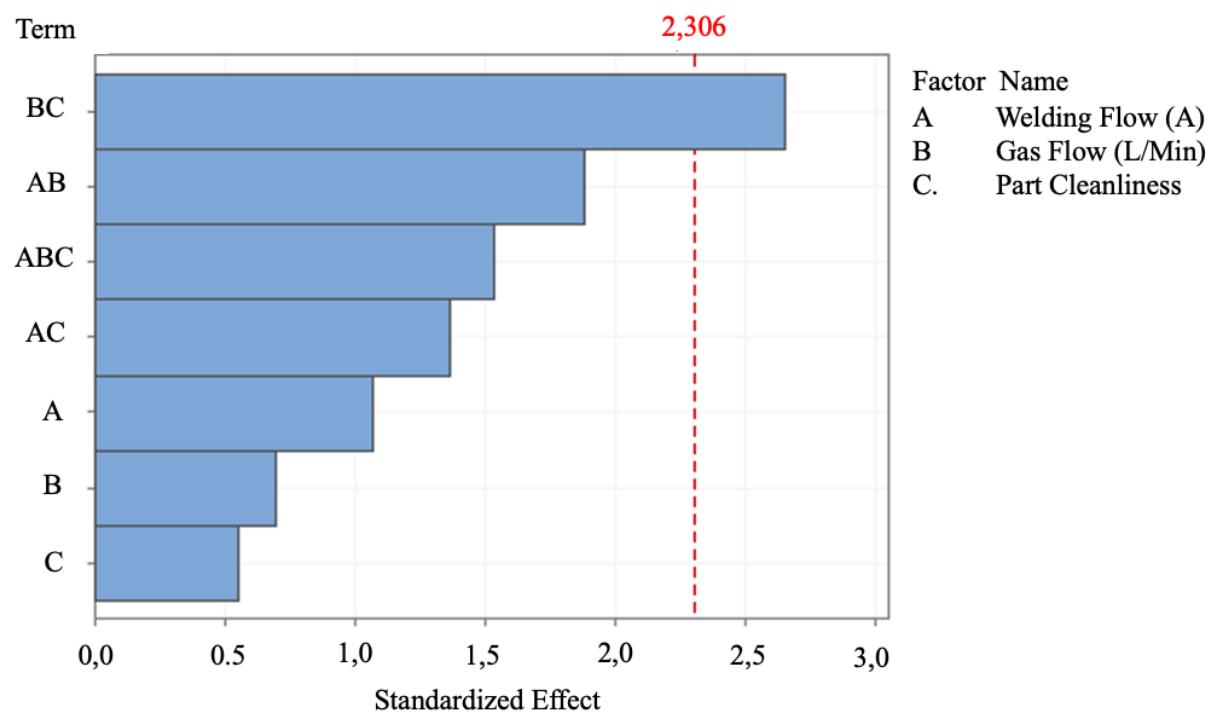

Fig. 9. Experimental design parameters interaction graph.

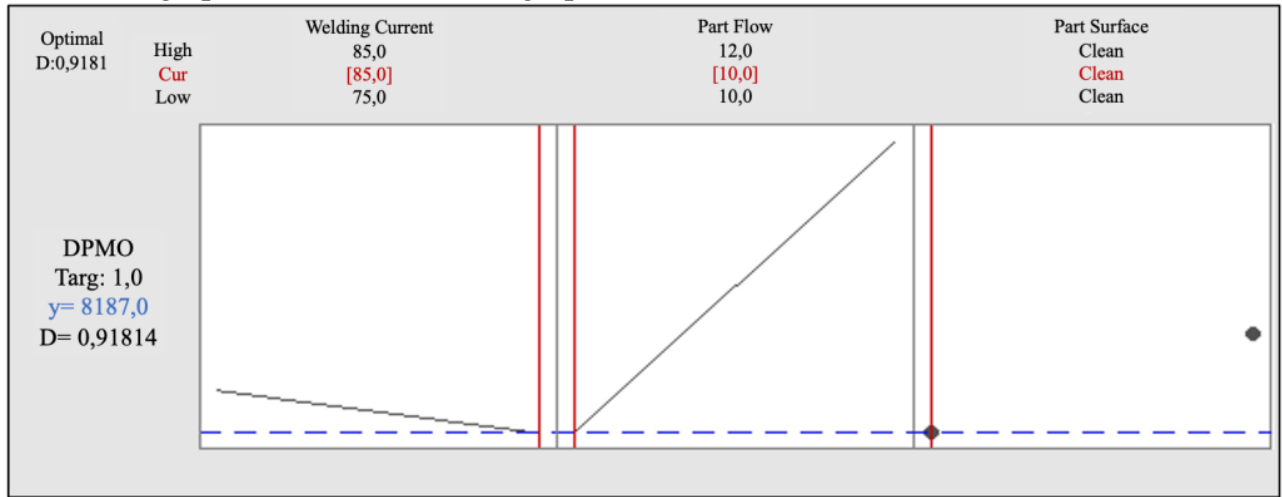

Fig. 10. Optimal parameter graph

Table 11. Experimental design parameters analysis table

\begin{tabular}{|l|r|r|r|r|r|r|}
\hline Coded Coefficients & \multicolumn{1}{|c|}{\begin{tabular}{l} 
T-Value \\
\hline Term
\end{tabular}} & \multicolumn{1}{c|}{ Effect } & \multicolumn{1}{c|}{ Coef } & \multicolumn{1}{c|}{ SE Coef } & \multicolumn{1}{c|}{ T-Value } & \multicolumn{1}{c|}{ VIF } \\
\hline Constant & & 24507 & 4309 & 5,69 & 0,000 & 1,00 \\
\hline Welding Current (A) & 9247 & 4624 & 4309 & 1,07 & 0,315 & 1,00 \\
\hline Gas Flow (L/Min) & 6031 & 3015 & 4309 & 0,70 & 0,504 & 1,00 \\
\hline Part Surface & -4788 & -2394 & 4309 & $-0,56$ & 0,594 & 1,00 \\
\hline Welding Current (A)*Gas Flow (L/Min) & 16265 & 8132 & 4309 & 1,89 & 0,096 & 1,00 \\
\hline Welding Current (A)*Part Surface & -11805 & -5903 & 4309 & $-1,37$ & 0,208 & 1,00 \\
\hline Gas Flow (L/Min)*Part Surface & -22917 & -11458 & 4309 & $-2,66$ & 0,029 & 1,00 \\
\hline Welding Current (A)*Gas Flow (L/Min)*Part Surface & -13268 & -6634 & 4309 & $-1,54$ & 0,162 & 1,00 \\
\hline
\end{tabular}

As seen in Table 11, it was determined that the gas flow and part surface composition had a significant effect on the result since the P-Value value was less than 0.05, while the other parameters did not have significant effect on the result because their P-Value values were greater than 0.05 .

The parameter that should be used to produce the least defective part was calculated using Minitab19 software as seen in Figure 10. According to the analysis result, the most appropriate parameter to be used is Current: 85A, Gas flow: 10L/Min, Part surface: The surface has been determined as clean and these findings were standardized. The productions made during the control phase were made by considering the most appropriate parameter determined.

After the improvements were completed and the most suitable welding parameters were determined, samples of 500 pieces produced in 20 shifts were taken during the control phase and the number of defects was monitored. The results obtained are shown in the I Control chart in Figure 11. The situation before the improvement and the situation after the improvement are shown side by side in the graph. While an average of 41.7 defects was encountered in the measurement of 500 pieces before the improvement, an average of 8.7 defects was reached in the measurement of 500 pieces after the improvement. 


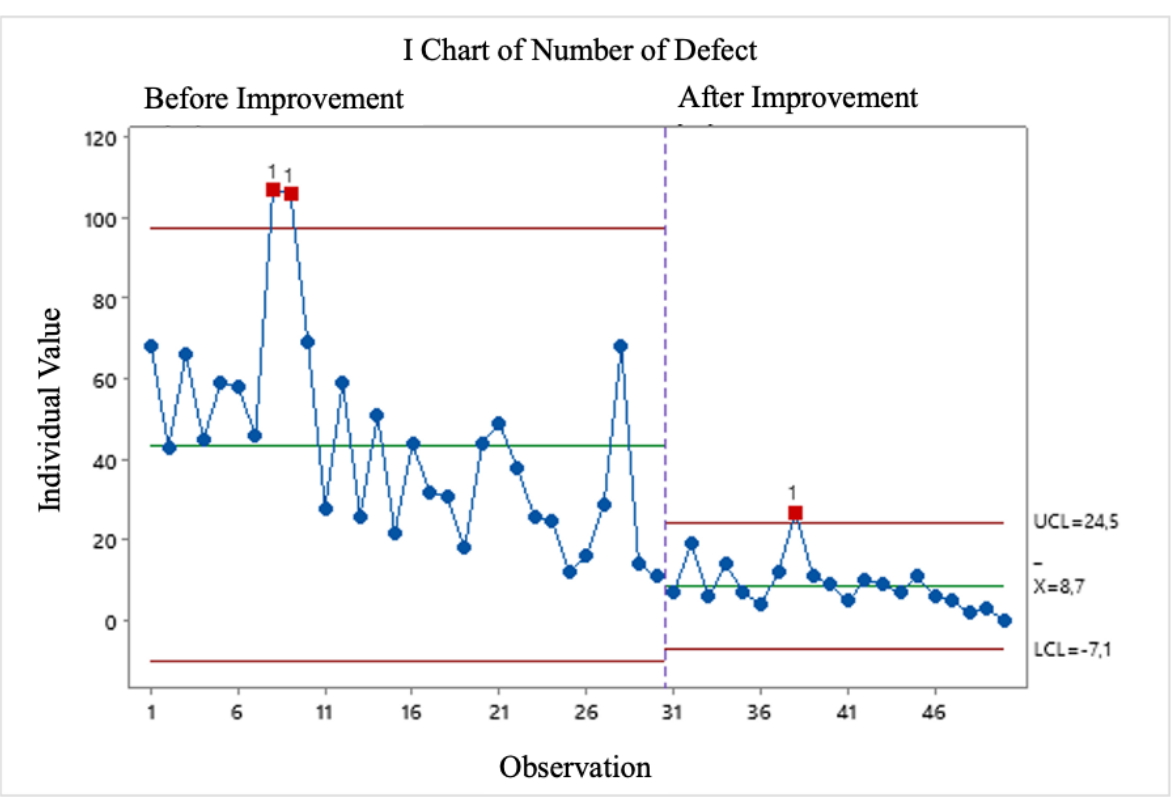

Fig. 11. I control chart before and after improvement

The sigma calculation before and after improvement is as follows;

Before improvement

DPMO: $(41,7 \div 500) * 1000000=83400$

Process Sigma: 2,88

After improvement

DPMO: $(8,7 \div 500) * 1000000=17400$

Process Sigma: 3,61

Difference: $3,61-2,88=0,73$ sigma improvement was achieved.

When the improvement is evaluated in terms of inbound logistics, it can be seen that the decrease in the number of scrap and rework in production leads the shipment from the sub-industry supplier to the main industry producer to be made in the planned time and amount. In this context, the total amount of stock and storage costs kept in the inventory of the main industry producer, which previously placed an early order in order not to run out of parts, had more stock on hand and incurred higher storage costs, decreased. As a result of the decrease in the defect rate, resulting from the quality controls performed while the parts are delivered from the supplier to the manufacturer in the main industry, the reverse logistics processes and costs of sending the defective parts to the supplier have decreased. In terms of environmental effects, the reduction in the amount of waste and scrap in production ensures that the waste of resources and energy is reduced in the entire inbound logistics process.

\section{Discussion and Conclusion}

While the Lean Six Sigma method reduces costs by reducing the number of defects in achieving improvement goals in business processes, it also reduces waste and environmental pollution by eliminating unnecessary activities. Sustainability is ensured by incorporating this approach into the business process of companies. By using the Lean Six Sigma approach, companies can work with their suppliers to provide the products or services they demand in a competitive supply chain structure.

In the study, the top management of both companies supported the Lean Six Sigma application and provided the necessary motivation. As the first step of the process, making the definition of the problem in an accurate, clear and understandable way constitutes the first step in keeping the process on the desired route and finalizing it. Making the definition of the problem clear and complete facilitates the solution. In this study, it was decided that the supplier's production process should be improved within the scope of inbound logistics in order to create a competitive supply chain structure. For this purpose, defect type, defect rate and number of defects were determined by drawing defect graph at the measure stage. Root causes were determined in the analyze part of the study. The analyzes should reveal the root causes and the factors causing the problem. For this reason, possible root causes were determined and scored by the fishbone and cause-effect matrix. Each of the root causes was observed in the production area, and evaluations were made for the improvement process. Experimental design method was used to estimate the effect of parameters such as welding current, gas flow and part surface specified in the study. After the trials, the most suitable parameter for improvement was selected and this parameter was standardized.

In the study, the improvement of the supplier's production process led to a decrease in the customer's stock level and storage costs in terms of inbound logistics, reduction of reverse logistics processes and costs, and reduction of resource and energy waste. In addition, improvements made as a result of root cause observations are standardized in control plans and 
FMEA. Otherwise, if the necessary standardization activities are not implemented, a reversion to the old situation may occur. Reducing waste provides environmental gains, however, it would be more appropriate to conduct a lean six sigma study focusing on this issue in order to determine the environmental impacts or costs.

In future studies, simultaneous Lean Six Sigma applications for different processes of supply logistics can be realized. Thus, the effect of the improvements made on the whole supply chain can be seen more concretely. Likewise, the environmental impacts can be directly evaluated with the improvement works to be carried out by taking into account the environmental management systems.

\section{References}

ASQ. (2021). Six Sigma. $05 \quad 2021$ tarihinde https://asq.org/quality-resources/six-sigma

Bhattacharya, A., Coleman, J., Brace, G. (1995). Repositioning the supplier: an SME perspective. Production Planning \& Control The Management of Operations, 6(3), 218-226.

Christopher, M., Rutherford, C. (2004). Creating Supply Chain Resilience Through Agile Six Sigma. Critical Eye, 24-28.

Desai, D. K. (2010). Six Sigma. Mumbai: Himalaya Pub. House.

Dombrowski, U., Karl, A. (2016). Systematic Improvement of Supplier Integration within the Product Development Process. Procedia CIRP, 57, 392-397.

Fraser, N., Fraser, J. (2011). Lean Six Sigma applied to a Customer Services Process within a Commercial Finance Organisation - An Empirical Case Study. International Journal of Business and Social Science, 2(9), 24-36.

George, M. L. (2002). Lean Six Sigma. McGraw-Hill.

Girmanová, L., Šolc, M., Kliment, J., Divoková, d., Mikloš, V. (2017). Application Of Six Sigma Using Dmaic Methodology In The Process Of Product Quality Control In Metallurgical Operation. Acta Technologica Agriculturae, 20(4), 104-109.

Gutierrez-Gutierrez, L., Leeuw, S. d., Dubbers, R. (2016). Logistics services and Lean Six Sigma implementation: a case study. International Journal of Lean Six Sigma, 7(3), 324-342.

Huo, B., Gu, M., Wang, Z. (2019). Green or lean? A supply chain approach to sustainable performance. Journal of Cleaner Production(216), 152-166.

Jejani, G. R., TarannumS, A., Jain, S. (2019). The Impact of Inbound and Outbound Logistics on the Supplier-Customer Relationship. International Journal of Innovative Research in Science, Engineering and Technology, 8(8), 8735-8739.

Kehoe, D., Boughton, N. (2001). Internet based supply chain management A classification of approaches to manufacturing planning and control. International Journal of Operations \& Production Management, 21(4), 516-524.
Krishnan, B. R., Prasath, K. A. (2013). Six Sigma Concept and Dmaic Implementation. International Journal of Business Management \& Research, 3(2), 111-114.

Kumar, D. (2006). Six Sigma Best Practices: A Guide to Business Process Excellence for Diverse Industries. Fort Lauderdale FL: J. Ross Publishing.

Linares, M. L., Christo, E. d., Costa, K. A. (2019). Lean Six Sigma in the Logistics of the Loading Process of a Paper Mill. Exacta, 17(3), 191-200.

Mijajlevski, A. (28 - 30 November 2013). The Six Sigma Dmaic Methodology In Logistics. 1st Logistics International Conference, (227 - 232). Belgrade.

Park, S. H. (2003). Six Sigma for Quality and Productivity Promotion. Tokyo: Asian Productivity Organization.

Satıc1, S., Satıc1, R., Özcan, B. (2020). Programlanabilir Güç Cihazinin Ölçüm Yeterliliğinin Gage R\&R İle Analiz Edilmesi. Işletme Bilimi Dergisi, 8(3), 427450.

Smętkowska, M., Mrugalska, B. (2018). Using Six Sigma Dmaic to Improve the Quality of The Production Process: A Case Study. Procedia - Social and Behavioral Sciences, 238, 590-596.

Takita, A. M., Leite, J. C. (2016). Inbound Logistics: A Case Study. Business Management Dynamics, 5(12), 14-21.

Tennant, G. (2002). Design For Six Sigma: Launching New Products And Services Without Failure. Burlington Vt: Gower Pub Co.

The Council for Six Sigma Certification. (2018). Six Sigma A Complete Step By Step Guide. Buffalo Wy.

Thomsett, M. C. (2005). Getting Started In Six Sigma. New Jersey: Wiley.

USEPA. (2020). www.Epa.Gov

Verma, A., Seth, N. (2019). Achieving Supply Chain Competitiveness: Some Critical Issues. International Journal of Engineering Science And Technology, 2(11), 6209-6213.

Yıldırım, H., Aydoğan, H., Özcan, S., Eti, S. (2018). Fazi Kontrol Grafikleri Ile Klasik Kontrol Grafiklerinin Karşılaştırılması Üzerine Bir Deneme. Journal of Research In Business, 3(2), 150-173.

Zhang, A., Luo, W., Shi, Y., Chia, S. T., Sim, Z. H. (2016). Lean And Six Sigma In Logistics: A Pilot Survey Study In Singapore. International Journal of Operations \& Production Management, 36(11), 1625-1643. 